\title{
Territorial development in today's Romania: the strenuous quest for a European patterned regionalization
}

\begin{abstract}
The rationale of this paper would be extracted from the fact that a regional policy, in the full European patterned comprehensive sense, was never thoroughly pursued in Romania since joining EU in 2007. Our research try to evaluate if there are any preliminary historical assets in order to ease the process of modern regionalization and further on to investigate the policies that were officially implemented in order to comply with the overall EU territorial developmental framework. Last but not least we investigate the ad-hoc approaches of several of the local public administrators in the country, innovative approaches conceived in order to mend the evident lack of consistency of governmental public policies in this area. Within this respect our endeavor is to benchmark the overall progress of the country towards genuine regional development to some recently taken steps by some local administrative bodies, steps that already proved to be lucrative for a few counties in North-Western Romania.
\end{abstract}

Key words: regionalization; territorial development; local administration; regional policy

\section{Starting points}

$\mathbf{T}$ he historic process of investigating the alternatives for diminishing all categories of transaction costs, a task continuously pursued since the inception of economic science, witnessed in time variations that indicated at one extreme the fact that only globalization could rationally respond to such a challenge and at the other end that "acting local" and reducing entropy by all means is the option in the contemporary, strategically bound towards sustainability, economic climate. In this respect, a lesser than national territorial, regional economic approach seems a more appropriate framework for Europe, obviously for a plethora of interdisciplinary arguments, and it is precisely this idea that we would like to convey through our approach focusing on the Romanian case.

Our primary target within this research is to interpret some of the issues correlating the present day lagging regionalization process that is based on economic arguments debate, with historic, geographic, demographic, cultural, social or business and environmental features that might be relevant for the country and worth taking in consideration in terms of policies and/or actions that should occur in the predictable future. Relevant sources point to the reality that the multidimensional cultural factor plays an increasingly important role in both processes of globalization and regionalization (Meyer, 2001). In this respect, we start from the derisive reality that Romania's regional policy has been bluntly described as induced "Europeanization," pointing to the reality that successive 
Romanian political establishments endorsed after 1989 the blueprint of a regional territoriality of NUTS II type explicitly designed for the purpose to absorb EU funds.

Meanwhile the historic perspective, as much as observed, has been bypassed with negative consequences in our opinion, thus leading to indefinite postponement in the area of regional administrative framework, from legal and consequently economic angles. It is our strong belief that the country gathered enough critical mass in order to trigger a true debate and ultimately elaborate on the endogenous regional approach that could be the economic main lever for sustainable development in the years to come. In other words, a dual process, of both exogenous (obviously of EU inspiration) and endogenous consistencies.

\section{Territorial Development in Romania: the Historical Angle}

Since the creation of modern Romania in the second half of the 19th century various archetypal patterns of regionalization could be observed as far as 1862 (Covăsianu, 2011, pp. 34-36). But we must acknowledge that no real process of the kind was operational and consequently not much economic impetus could be attributed to the territorial re-arrangements following the creation of the Romanian principalities. Until the First World War many of the characteristics of what we can brand as regional economy were heavily under the burden of a resilient feudal system that was indicative not only for Romania, but also for most of the Eastern European countries.

The 20s and 30s were years of systematic growth, obviously pushed forward by the significantly increased domestic market, but also years of unbalanced development, with a few competitive industries located mostly in the new provinces and an extensive and labor intensive agriculture representative for most of the country's territory. A detailed description of the issue of the 20's and 30's as seen from a Romanian economic perspective is available in Păun (1992). In 1929 for instance, before international crisis broke, agriculture and forestry accounted for $72 \%$ of the Romanian GDP, while industrial activities and services of all types accounted for only 18\% (Păun, 2009).

In 1929 a law for the organization of the local administration (Law No. 167/1929) was pushed forward by the National Peasant's Party (NPP), a champion of decentralization of public administration, for reasons stretching from the history of the national struggle in Transylvania to ideological positioning. The seven Ministerial Directorates dividing the Romanian territory according to this law were in fact macro-regions with strong historical ties and also economic consistency. But in full truth, they were conceived for mainly administrative purposes and therefore had little or no impact on the day by day business life. Overall we can observe an interwar years relative status quo of the issue of regionalization, situation that is broken only in the late 30s, under German influence, when between the years 1938-1940 when the German Gaus were replicated in Romania as tinuturi (territories) though there is no track of historic consistency whatsoever in them. Accordingly, their lifespan was drastically limited.

The post-war years were obviously under the heavy Soviet influence. From a territorial perspective, we can notice only one asset of the period, namely the push-up of industrialization that occurred more or less even in all Romanian provinces, priority being 
given to less developed areas such as Moldavia. It is highly debatable if the model of socialist industrial development (with its initial Stalinist phase, to be followed by a specific national approach) inaugurated in the 50s is in fact an endogenous answer, a sui generis "by ourselves" set of policies. And whatever happened in a spatial perspective its inception was the 1968 territorial administrative re-organization, which recuperated much of the interwar framework of the kind. But even more important would be the fact that the new frame of Law 2/1968 established initially 42 counties (judeţe) and two years later 39 plus the Capital city, entities that were designed after two years of studies that went on cultural, geographic, socio-economic, etc. tracks.

The territorial approach was significantly under scrutiny since 1976, when the National Territorial Plan (NTP) was issued and consequently the 1968 administrative grid became much more consistent form the spatial developmental perspective. The plan imposed a developmental model having as main target a social one, namely the diminishing of differences in the standard of living observed in various counties but also historical provinces (macro-regions). It was meant to improve significantly the linkages between different areas of the country, to regularize the flow of the major rivers, to control the relative chaotic urbanization, etc. - all these in order to facilitate a more rapid pace of economic growth.

The most dramatic territorial discourse of the communist regime occurred in the late 80 s and was by far also the most controversial. The new Law of territorial administration that was issued in April 1989 would endorse the so called policy of "rural systematization" policy that was meant to re-organize the area of the country from the urban-rural perspective in order to increase the efficiency of the use of land. Apparently, there were good reasons for this view: while one of the most endowed naturally countries in Europe, Romania was significantly lagging behind in terms of agricultural productivity.

Starting with the early ' 90 s, Romania's regional policy turned to be a classical effect of "Europeanization". And it should be mentioned, that it was EU that initiated the systematic regional discourse through its pre-accession framework. Following the preliminary results, a Green Card concerning regional development and the Law of Regional Development (151/1998) were passed. Rather soon the political will imposed a territorial mainframe consisting in 8 development regions of NUTS $\mathrm{II}^{2}$ consistency. We must observe that much of today's development disequilibria is being attributed to the outcome of decades of communist management but less to the policies that were implemented starting with the ' 90 . Which could be a very misleading path indeed.

${ }^{1}$ An interesting classification of the constraints inducing major trends: globalization and Europeanization are constraints "from above" while political culture would be "from below" - Between Europeanization and Local Societies, The Space for Territorial Governance, J. Bukovski, S. Piattoni and M. Smyrl, Eds., Rowman and Littlefield Publishers, Lanham, Boulder, New York, Oxford, 2003, pp. 2 - 7.

2 The Nomenclature of Territorial Units for Statistics (NUTS) as established by Eurostat in order to provide a single "uniform breakdown of territorial units for the production of regional statistics"; although NUTS has no legal value per se throughout EU, NUTS was in place since 1988, the reviewed 1999 version indicating five levels. These show the following pattern in the case of Romania: NUTS I: the whole country; NUTS II: 8 development regions; NUTS III: 42 counties (old pre-war administrative frame); NUTS IV: not applicable (usually EU pattern indicate territorial associations, mainly big cities); NUTS V: 265 municipalities and towns and 2686 rural communities (13092 villages). 


\section{The Framework of Governmental Regional Policy in Recent Times}

The existing regional territorial framework "benefits" of two kinds of major liabilities: on the one hand and deriving from this "birth sin" is the lack of decisional power on behalf of the administrators of this domain of regionalization. From both perspectives, nation- or region-wide, real managerial power belongs either to the government or counties' administrative decisional layers, much less aware of EU's procedures, techniques, not to say sustainable developmental philosophy. Therefore, on can observe an evident lack of professionalism in tackling with the issues deriving from projects' management,

On the other hand the regional deciding bodies, as much as they exist, perform a role of vehicles for the re-distribution of resources and wealth in order to build a more or less economically homogenous country. Such a typology of policy is acceptable within specific boundaries (such as for short-medium period, for preventing foreseen crises, etc.) but would be definitely negative on the long run due to the fact that it would inevitably replicate communist era policies, and also because it creates in fact dependency through artificial shielding via a redistributive system truly counter-productive in terms of competitive advantage. The less developed historical province of Romania, namely Moldavia, but also some Southern areas fully illustrate this pattern.

There are a few main trends that could be observed as present in the national debate concerning this issue today: decentralization, a better territorial administrative apparatus and the subtle equilibrium between central and local powers.. The regionalization process in Romania requires primarily the effective "re-creation" of the future regions that will have to be more or less financially self-sustainable. This optimality criterion is hard indeed to acquire under the present Romanian political circumstances but not impossible, provided critical mass of political will is reached. Those regions must have a complete administrative autonomy so that they will be directly responsible for the development and growth of that territory.

Only and only in such an administrative environment we can talk about common strategic (mainly infrastructural) projects across EU regions. Only in such a juncture is also acceptable for them to create a stock of solidarity between them, of probably no more 5 to $10 \%$ of the income earned by each region. Thus, the inability of the government to set a reasonable equilibrium for the budgetary allocation will vanish and the plethora of approaches branded as favoritisms would be expelled from the system.

\section{Local and Regional Innovative Approaches}

Sustainable territorial development, as targeted in this paper, was defined by the Brundtland Comission as far as 1987 but for various reasons in has fallen into a sort of shadow for a long time. It is only in 2005 that the European institutions started to evaluate the progress and it was only in 2006 that they adopted a coherent strategy. EUs Strategy for sustainable development is grounded on at least seven important pillars: climate change and clean energy; sustainable transportation; sustainable output and consumption; natural resources management; public health; social inclusion; wealth and global challenges. This approach has been both complemented and up to a certain point 
overlapped by the Lisbon Strategy, grounded on the three major pillars: competitiveness, social inclusion and protection of the environment. This would be our perspective when analyzing the specific state of the affairs in the North-Western Development Region (NWDR) and Western Region (WR) of Romania.

NWDR is administratively gathering Cluj county, historically speaking the socialcultural capital city of Transylvania, and other 5 counties (Bistrita, Salaj, Maramures, Satu Mare and Bihor) of Greater Transylvania (including the historical provinces of Crisana and Maramures, as well as parts of Banat, currently in the Western region). It was and it is considered to be one of the most developed regions, owing that both to tradition and to the more innovative approaches that were quite common in the area, in a comparative, nationwide assessment. The essence of the regional approach in NWDR since the early 90 s was embedded in the main idea to increase the attractiveness of the whole region and provide a reasonable ground for foreign investments.

The two regions remain significantly polarized in terms of GDP and income/capita and though several regional poles for economic development (mainly Cluj-Napoca, Timisoara, Arad and Oradea) proved potential, the dissemination effect was fatally jeopardized by the centralized administrative framework. This leads to the interrogation about the effectiveness of the process, especially due to the fact that during the years of boom (2004-2008) NWDR and WR proved to be a territory attracting many businesses, including high tech industries as well as various services de-located from abroad by multinational corporations.

Actually the demand for effectiveness pushes towards a different approach, implying a sort of symbolic capitalization of the centre as opposed to whatever is considered to be a periphery of the system, capitalization that allows to identify the main features of that peculiar economic space, the status of its inhabitants and meanwhile generates a specific centripetal dynamic that generates a specific favorable attitude towards the centre. The very core of the cluster becomes an identifier of the people and output, just as the proto urban planners of the Middle Ages balanced very well the relationship between centre and periphery, by enhancing the role of the main square. As Schoales (2006) underlines the so-called location share differential, practically imposing to regions to be different and get more different as benchmarked to a national or international entity. Belonging to the centre motivates (at least virtually) people, organizations, businesses, to perform better and to sustain a certain status. It is precisely what we support through extended innovative clustering in NWDR an WR. And the most pertinent example we can bring to surface would be the obvious alpha cluster of the region, the Cluj Metropolitan Area (CMA).

Initiated right after EU accession in 2007, but at the height of the economic boom in Romania, CMA would be an area of about 1500 square kilometers, about 450.000 inhabitants of Cluj-Napoca and other 16 relatively small neighboring communities, having a multitude of economic branches and relevant production density, reasonable well developed infrastructure, educated workforce, competitive R\&D facilities, decent educational and health services and a pleasant environment. The project got somehow frozen in 2009, when the crisis hit, but not before generating lots of comments and PEST and SWOT type of analytical interpretations and even some informal follow-ups.

No strategic planning of the town and area occurred since that moment without having at least some sort of CMA input. Even more, the identified development poles, other 
than CMA, started to think and act in a more comprehensive manner, beyond the formal Regional Operational Plan that would be the main channel of fund absorption, managed by the Regional Development Agency (RDA) of NWDR. At this stage, a major infrastructural approach, opened a wide window of opportunities, namely the A3 (Transylvania) highway trajectory that is virtually cutting through the whole DR, making potential stakeholders in the region to re-evaluate their business plans and give them at least a zest of regional wrapping.

The present day outlook gives us reasonable grounds to assess that clustering for development, as expected in NWDR and WR would occur along with a process of adopting more and more innovative paths. As Hilpert et al. (2003) points out, diversity and initial disparity are prerequisites for a successful regional track, but in the present day EU integrative juncture the initial conditions could not matter less, if a "smart" policy framework is put in place. Meanwhile the exogenous (definitely read global) factors could and eventually would play a larger role than domestic, governmental policies of the kind. But for the Romanian situation that would imply without doubt a complete re-interpretation of the administrative "decision taking" procedure.

Just as the Romanian, economy is "peripheral" within the macro-frame of the EU in terms of a quantitative approach, full integration cannot but underline a scale of becoming more peripheral, or on the contrary, of getting beyond this situation. It is hard to assess at this stage if "de-periphery-zation" could be accomplished at regional level, or if the central government (the Romanian "French" type of governmental centralization being a relevant example in this respect) would accept to loosen the grip in this respect. That would imply approving a comprehensive de-centralization of the decision through the creation of regional fully empowered decision bodies, but pessimists should acknowledge that in a rather comparable situation, more than a decade ago, Poland went ahead on this path.

As detailed by Dan and Maniu (2019), the regionalization process in Romania is stalling, with multiple attempts from the post-EU accession period being de facto failures, namely (1) the first regionalization debate, initiated by the main Hungarian minority party, who were promoting a structure based on ethnical criteria, disregarding most economic and social realities, (2) the 2011 Boc government initiative, which did not however materialize into a government bill at that time, and (3) the 2013 Ponta government proposal for a format consisting of eight regions (including a geographically smaller region centered around Bucharest) based on the structure of the existing NUTS II framework. Since 2013, the regionalization topic fell short of making the social and political spotlight at a national level. This absence, local authorities, especially those that are frustrated by the government allocation of funds, are more likely to try finding alternative solutions that would allow a more leeway and additional instruments regarding regional development and the accomplishment of regionally defined objectives.

In this context, the most visible such action by local authorities is represented by the formation of the Alliance of the West (AW), an inter-local alliance of four of Transylvania's biggest cities (namely Cluj-Napoca, Timisoara, Arad and Oradea) aimed at partially counterbalancing the centralized Romanian public governance structure by, as the AW official documents show, (1) ensuring a radically improved mobility and accessibility in the four founding cities, (2) offering support for active measures of economic and social 
development, (3) collaborating in order to identify and implement measures leading to improved administrative performance and (4) promoting the European model of public policy, in line with the principles pertaining to increasing knowledge and promoting/ consolidating culture (Alianta, 2018). Moreover, the same document reveals the AW ambition to circumvent the national government and obtain EU funding directly, a move that would not be in line with the trend identified by Brezovnik, Oplotnik and Vojinovic (2015), who argue that, the financial crisis has generated a tendency for centralization of public procurement in the EU, opposing the highly decentralized systems in place in certain Member States.

AW represents the best Romanian example of scalecraft, a concept defined by Henderson (2019) as "a particular form of statecraft [that] can involve regional inter-local government collaboration," in the context of which, Henderson argues, advocacy-based efforts to forge stronger inter-government alignments should be taken into consideration as a distinct feature of the multi-level commitment to regional action. Such an approach, consisting of reflexive local actors, may be able, as Lindsey (2014) notes, to develop more effective forms and practices of collaboration by collectively addressing contextual challenges. Also, such structures may have beneficial effects regarding stakeholder inclusion, a situation that may influence public sector project innovation (Godenhjelm, Johanson, 2018). Last but not least, local policy networks have been considered to exhibit a surprising level of stability, as seen from the perspective of local policymakers, a study on Dutch local policy networks concludes (De Vries, 2008).

According to Nicolae Robu, the mayor of Timisoara at the time of AW constitution and the first AW president, the structure is based on the principles of local development and resource optimization and aims concentrating power at a local level, with concrete results at intra- and interregional levels (Robu, 2019). As Ilie Bolojan, the mayor of Oradea between 2008 and 2020 and the current President of the Bihor County Council (the county in which Oradea is located) noted, the AW initiative is not aimed at challenging governmental prerogatives, but should be viewed as an exemplification of the principles of local autonomy, association and subsidiarity (Bolojan, 2018). These views are consistent to those of Emil Boc, the mayor of Cluj-Napoca, who considers that the current Romanian model of centralization is obsolete, as only decentralization may enable all drivers of economic development, an endeavor that AW is committed to (Boc, 2018).

However, political voices, mainly pertaining to persons affiliated to the, at the time, governmental party (in contrast with the affiliation to the opposition of the four mayors that launched the AW project), criticized the move and expressed concerns that it would lead to fragmentation and even endangering the state's constitutional unity, claims that the representatives of AW have repeatedly dismissed. This contrarian stance is currently tested by the fact that, after the September 2020 local elections, three of the four funding mayors are no longer in function (Timisoara, Arad and Oradea, with Timisoara having a mayor from another party, while Arad and Timisoara are still headed by PNL members). On the other side, PNL (the party of the four funding mayors) has meanwhile become the main party within the government coalition. However, it remains to be seen if AW can find the necessary support (either in the initial form, or in a changed configuration) in the new local and national political configurations. Nonetheless, this clash needs to be analyzed in the context of the internal vs. external legitimacy debate, as synthetized 
by Provan and Kenis (2008), who argue that legitimacy is a critical network-level tension that "arises when the internal legitimacy needs of network members conflict with external demands," with effective network governance implying the capacity to develop structures that are responsive to both internal and external legitimacy criteria, an objective that cannot be accomplished, the scholars argue, by employing a single one-network governance form. Even though just in its incipient phases of development, this is one of the elements that AW needs to take into consideration in order to be able to ensure an efficient future structural design.

\section{Conclusions}

The endogenous view concerning a mainly protectionist analysis of the Romanian economy of the 30s, carried by Mihail Manoilescu and depicting somehow the generic situation of all the emerging economies (Manoilescu, 1986) seems to us an appropriate historical example of the necessity to enhance by all means the territorial pushing factors for the sake of accomplishing well balanced sustainable development hopefully today, mandatory in the predictable tomorrow's Romania. Unfortunately, the presentday legislation of the domain, notably the Law of Regional Development (151/1998 - modified in 2004) managed only to answer the issue for the short run, and for tactical purposes such as EU fund absorption. The present day 8 development regions that hardly suggest an EU compatible regional outlook are definitely not a strategic solution for the overall territorial development of this country. Although far from providing a long term solution to the shortcomings of the current Romanian regionalization structure, regional or even local alliances, such as the Alliance of the West, could prove to be beneficial, as they, even if in a limited manner, have the potential of bringing a certain level of de facto decentralization and thus increasing the efficiency of the economic development process.

\section{Bibliography}

Alianta V. (2018) AVE - Alianta Vestului. O initiativa in spiritual declaratiei de la Alba Iulia. Viziunea Noastra. Cele 4 principii fundamentale ale Aliantei.

Boc E. (2018), Public declaration, as reported by Florea, Sebastian, 'Alianţa Vestului': Stop migrației. Documentul semnat de patru primari, DC News, $8^{\text {th }}$ of December 2018, https://www.dcnews.ro/ alianta-vestului_627448.html, 24.07.2019.

Bolojan I. (2018), Public declaration, as reported by Ivanov, Catiusa, Alianța Vestului, o alternativă pentru românii care vor să migreze? Primele proiecte concrete: Drum expres de $110 \mathrm{~km} s ̧$ linie electrificată între Oradea şi Arad, hotnews.ro, $11^{\text {th }}$ of December 2018, https://www.hotnews.ro/stiri-administratie_locala-22859595-alianta-vestului-alternativa-pentru-romanii-carevor-migreze-primele-proiecte-concrete-drum-expres-110-linie-electrificata-intre-oradea-arad. htm?nomobile $=$, 24.07.2019.

Brezovnik B., Oplotnik Z. J., Vojinovic B. (2015), (De)Centralization of Public Procurement at the Local Level in the EU, "Transylvanian Review of Administrative Sciences", no. 46E, pp. 37-52.

Bukovski J., Piattoni S., Smyrl M. (eds.) (2003), Between Europeanization and Local Societies, The Space for Territorial Governance, Rowman and Littlefield Publishers, Lanham-Boulder-New York-Oxford, pp. 2-7. 
Covăsianu A. (2011), Regiunile de dezvoltare în România europeană. Intre deziderat politic şi realitate teritorială, (UAIC Iaşi, phD Thesis, 2011), http://www.academia.edu/1165575/Regiunile_de_dezvoltare_\%C3\%AEn_Rom $\% \mathrm{C} 3 \% \mathrm{~A} 2$ nia_european $\% \mathrm{C} 4 \% 83.0 \mathrm{C} 3 \% 8$ Entre_deziderat_politic_\%C8\%99i_realitate_teritorial\%C4\%83, April 7, 2019, pp. 34-36.

Dan H., Maniu M. (2019), The Incomplete Regionalization Process in Romania and the Unfulfilled Potential for Enhanced Growth Catalyst Structures - a Critical Analysis, unpublished manuscript.

De Vries M. (2008), Stability despite reforms: Structural asymmetries in Dutch local policy networks, "Local Government Studies", vol. 34, no. 2, pp. 221-243.

Godenhjelm S., Johanson J.-E. (2018), The effect of stakeholder inclusion on public sector project innovation, "International Review of Administrative Sciences", vol. 84, no.1, pp. 42-62.

Henderson S. R. (2019), Framing regional scalecraft: insights into local government advocacy, "Territory, Politics, Governance", vol. 7, issue 3, pp. 365-385.

Hilpert U. (ed.) (2003), Regionalization of Globalised Innovation, Routledge, New York.

Legea 167/1929 (2015) at Lege5.ro, Bucharest, http://lege5.ro/Gratuit/gezdiobuge/legea-nr167-1929-pentru-organizarea-administratiunii-locale, August 7, 2018.

Lindsey I. (2014), Prospects for Local Collaboration into an Uncertain Future: Learning from Practice within Labour's Partnerships Paradigm, "Local Government Studies", vol. 40, no. 2, pp. 312-330.

Manoilescu M. (1986), Forţele naţionale productive şi comerţul exterior. Teoria protecţionismului şi a schimbului international, Editura ştiinţifică şi Enciclopedică, Bucharest.

Meyer T. (2001), The Cultural Factor in the Process of Globalization/Regionalization, in: European Union and New Regionalism, ed. M. Telo, Asgate, Aldershot, pp. 59-67.

Păun N. (1992), Stat si economie, Romania in perioada interbelica, Editura Interferente, Cluj-Napoca.

Păun N. (2009), Viața economică a României: 1918-1948: modernuzare - dezvoltare - europenizare, Presa Universitară Clujeană, Cluj-Napoca.

Provan K., Kenis P. (2008), Modes of Governance: Structure, Management and Effectiveness, "Journal of Public Administration Research and Theory", vol. 18, no. 2, pp. 229-252.

Robu N. (2019), Public declaration, as reported by Dancea, Dani, A fost înfiinţată Alianţa Vestului. Timişoara, Arad, Oradea şi Cluj-Napoca se asociază ca să atragă bani europeni pentru proiecte majore, Adeavrul, $8^{\text {th }}$ of December 2018, available online at https://adevarul.ro/locale/timisoara/document-fost-infiintata-alianta-vestului-timisoara-arad-oradea-cluj-napoca-asociazaatraga-bani-europeni-proiecte-majore-1_5c0be3f1df52022f75402db7/index.html, 24.07.2019.

Schoales J. (2006), Alpha Clusters: Creative Innovation in Local Economies, "Economic Development Quarterly", SAGE, no. 20, pp. 162-177.

\section{Rozwój terytorialny współczesnej Rumunii: trudne dążenia do realizacji europejskiego modelu regionalizacji}

\section{Streszczenie}

Uzasadnieniem niniejszego artykułu jest fakt, że polityka regionalna, w pełnym europejskim znaczeniu tego słowa, nigdy nie była dokładnie realizowana w Rumunii od momentu przystąpienia do UE w 2007 roku. Nasze badania próbują ocenić, czy istnieją jakieś wstępne historyczne atuty, które mogłyby ułatwić proces nowoczesnej regionalizacji, a następnie zbadać polityki, które zostały oficjalnie wdrożone w celu dostosowania się do ogólnych ram rozwoju terytorialnego UE. Wreszcie badamy podejścia ad hoc kilku lokalnych administratorów publicznych w kraju, innowacyjne podejścia opracowane w celu naprawienia oczywistego braku spójności rządowych polityk publicznych w tej dziedzinie. W tym kontekście naszym celem jest porównanie ogólnego postępu kraju w kierunku praw- 
dziwego rozwoju regionalnego z pewnymi krokami podjętymi ostatnio przez niektóre lokalne organy administracyjne, krokami, które już okazały się dochodowe dla kilku powiatów w północno-zachodniej Rumunii.

Slowa kluczowe: regionalizacja; rozwój terytorialny; administracja lokalna; polityka regionalna 